\title{
The system of educating primary school students to care positively about the environment environmental education in primary school
}

\author{
Kodirova Muhayyo Salievna ${ }^{1}$, Bovanova Umida ${ }^{2}$ \\ ${ }^{I}$ Kokand CPI Associate Professor of Primary Education, Uzbekistan \\ ${ }^{2}$ Denov Institute of Entrepreneurship and Pedagogy, Uzbekistan
}

Email:kodirova_m@umail.uz.

\begin{abstract}
This article focuses on environmental issues. Special attention is paid to the methods and ways of forming ecological culture in primary school.

Keywords: Ecology, ecological culture, ecological education, conscious attitude, extracurricular activities, observation, practical work, etc.
\end{abstract}

\section{INTRODUCTION}

After gaining independence, the Republic of Uzbekistan has been carrying out important reforms, new approaches and research in all areas. Special attention is paid to the education of students in the education system is given. Thanks to the initiative and consistent activity of our President in our Republic a national training program has been developed and is being phased out is being done. Special attention is paid to the environment.

At present, ecological science is taught in all educational institutions of the Republic. In particular, in the process of continuing education, environmental education in preschool education begins with acquaintance with the surrounding nature and the world around us. In-depth study of this topic will be explored through subjects such as "Health", "The World around Us" and "Natural Science" on the basis of elementary grades. But in the elementary grades, students receive their first knowledge in "Literacy Teaching" and then in "Reading" classes. Ecology embodies such noble human qualities as purity, good intentions, pure feelings, sacred knowledge of the soil, and love for the Motherland.

The formation of the ecological culture of students is formed, first of all, in the family circle and mainly in the circle of our teachers. Ensuring a bright future for Uzbekistan the Law on Education is reflected in the National Training Program. In this regard, one of the tasks of primary education is to develop students' awareness of the environment.

Successful solution of this task requires teachers to have in-depth knowledge in their field, high environmental culture, creativity, and training based on pedagogical technologies.

Only a teacher with such qualities should bring up a well-rounded person who has a deep theoretical knowledge of environmental education, knows the secrets of processes in nature, understands its socio-economic and spiritual significance, and has a conscious attitude to nature. In order to form an ecological culture, it is important to have ecological education.

Environmental education is, of course, based on environmental knowledge, but it also has its own characteristics. Environmental education works on the formation of a correct, rational attitude to nature in man, and sets itself the goal of forming an ecological culture in students. The content of ecological education includes ecological consciousness, ecological feelings (attitudes towards nature, people, life). Thus, environmental education plays an important role in human life, in society, in the homeland.

The formation of ecological education requires not only the acquisition of ecological knowledge, but also the formation of ecological relations. Environmental relations: attitude to life, fostering a sense of wholeness. Components such as fostering a sense of responsibility and a sense of the beauty of nature. Not only today, but also our ancestors took a deep responsibility for environmental education. For example, in order not to pollute the environment, separate pits were dug for littering, waste disposal, cutting down only dry trees for various needs, torturing animals, destroying bird nests, and considered it a sin.

In this regard, the family says, "Do not spit on water, do not pollute it, because all animals will enjoy drinking it," "Do not break the branch of a flowering fruit tree, it will bear fruit, you will eat it yourself," "Do not cut unripe grapes, if you cut It is a great sin to commit it, because it is the destiny of the believer." shaping them is one of the most important tasks. 
A variety of manuals, media, textbooks, and extracurricular activities are important resources for teacher teaching. Educating students to respect nature is not just about learning. Lessons are limited in time, and many important environmental knowledge cannot be taught to students. Extracurricular activities are not limited in time. Developing students' environmental knowledge in extracurricular activities can be effective.

In educating primary school students in a spirit of respect for nature, extracurricular activities are a continuation of what students have learned in the classroom and complement the content and integrate it into the whole process.

To do this, if today's teacher is inquisitive, active, creative, there is no doubt that the students he teaches will be mature and knowledgeable in all respects. With this in mind, the teacher should pay special attention to the content of the event, based on the nature of the topic: "From the first moment of birth, a person enjoys the gifts of nature. That is, for the first time, he breathes in the air. When a person is born and brought up by a mother, nature nurtures him. That is why it is called "Mother Nature". Mother Nature is overwhelmed by our love and compassion. Many animals and rare plants are being killed. Our only Aral Sea is on the verge of destruction. We are now careful with every tree, shrub, weed it is important to be able to engage them by giving examples such as how we should relate. If the above thoughts reach the child's mind, if he has in his heart a feeling of pity, compassion and care for the destruction of our nature, it is our happiness, that is, the happiness of teachers.

Extracurricular activities are also an additional and free form of education that allows students to expand their creative activities. Study tours are important for exploring the world around us. Travel lessons are an important tool in educating students about the environment as a form of learning. Cognitive activity is formed in the process of observing nature, students' understanding of the interaction of animate and inanimate nature, the flora and fauna is expanded.

In addition, environmental education for students during extracurricular activities is one of the tools for the comprehensive development of the student's personality. For example, the "Flower Festival" provides an opportunity to educate children in the spirit of the environment, which can be held in the classroom or between schools. Preparations for the event will begin a few weeks in advance. The children will take part in the event with a variety of flowers that they grow and care for. Through this activity, children will develop a love for plants learn to nurture and reproduce. The most important is ecology learn to contribute to conservation. There are many ways to introduce children to nature in the educational process and to form an ecological culture through ecological education. These include classes, games, excursions, work, and daily life.

This means that primary school students' understanding of environmental culture, the use of materials provided in textbooks directly to expand, integrative lessons, extracurricular and extracurricular activities, direct students to practical work (cleaning the environment, etc.). the implementation of environmental education through planting, gardening, planting flowers, looking for ways to save water) can shape the environmental culture in students. In conclusion, the primary school teacher should seek, find and use opportunities wisely in each lesson and extracurricular activities to create an ecological culture in the students.

\section{REFERENCES}

1. Karimov I.A. O'zbekistonning o'z istiqlol va taraqqiyot yo'li.- T: O'zbekiston, 1992.

2. Bozorova N. Uzluksiz ta ${ }^{e c}$ lim jarayonida masofaviy o'qitish metodi asosida talabalarda ekologik madaniyatni shakllantirishning ahamiyati. Uzluksiz ta"lim j.2006. № 3.

3. R.Mavlonova va b. "Pedagogika". Toshkent, "O'qituvchi”. 2000 y. 